\title{
Neonatal, infant, and child mortality among women exposed to intimate partner violence in East Africa: a multi-country analysis
}

Peter Memiah ${ }^{1 *} \mathbb{D}$, Tristi Bond ${ }^{1}$, Yvonne Opanga $^{2}$, Caroline Kingori ${ }^{3}$, Courtney Cook ${ }^{4}$, Michelle Mwangi ${ }^{5}$, Nyawira Gitahi-Kamau' ${ }^{6}$, Deus Mubangizi ${ }^{7}$ and Kevin Owuor ${ }^{8}$

\begin{abstract}
Background: Most neonatal, infant, and child deaths occur in low- and middle-income countries (LMICs), where incidence of intimate partner violence (IPV) is highest in the world. Despite these facts, research regarding whether the two are associated is limited. The main objective was to examine associations between IPV amongst East African women and risk of death among their neonates, infants, and children, as well as related variables.

Methods: Analysis was conducted on data drawn from the Demographic and Health Surveys (DHS) conducted by ICF Macro/MEASURE DHS in five East African countries: Burundi, Kenya, Rwanda, Tanzania, and Uganda. The analytical sample included 11,512 women of reproductive age (15-49years). The outcome variables, described by proportions and frequencies, were the presence or absence of neonatal, infant, and under-five mortality. Our variable of interest, intimate partner violence, was a composite variable of physical, sexual, and emotional abuse; chi-square tests were used to analyze its relationship with categorical variables. Adjusted odds ratios (aOR) were also used in linking sexual autonomy to independent variables.

Results: Children born to women who experienced IPV were significantly more likely to die as newborns (aOR= $1.3,95 \%$ confidence interval $[\mathrm{Cl}]$ : 1.4-2.2) and infants ( $\mathrm{aOR}=1.9,95 \% \mathrm{Cl}: 1.6-2.2)$, and they were more likely to die by the age of five $(\mathrm{aOR}=1.5,95 \% \mathrm{Cl}: 1.01-1.55)$. Socioeconomic indicators including area of residence, wealth index, age of mother/husband, religion, level of education, employment status, and mass media usage were also significantly associated with IPV. After regression modelling, mothers who were currently using contraceptives were determined less likely to have their children die as newborns ( $\mathrm{aOR}=0.5,95 \% \mathrm{Cl}: 0.3-0-7)$, as infants $(a \mathrm{OR}=0.5,95 \%$ $\mathrm{Cl}$ : 0.3-06), and by age five (aOR $=0.4,95 \% \mathrm{Cl}: 02-0.6)$.

Conclusion: Understanding IPV as a risk indicator for neonatal, infant, and child deaths can help in determining appropriate interventions. IPV against women should be considered an urgent priority within programs and policies aimed at maximizing survival of infants and children in East Africa and the wellbeing and safety of their mothers.
\end{abstract}

\footnotetext{
* Correspondence: PMemiah@ihv.umaryland.edu

${ }^{1}$ Division of Epidemiology and Prevention, Institute of Human Virology (IHV): University of Maryland School of Medicine, 725 W. Lombard Street, Baltimore, MD 21201, USA

Full list of author information is available at the end of the article
}

(c) The Author(s). 2020 Open Access This article is distributed under the terms of the Creative Commons Attribution 4.0 International License (http://creativecommons.org/licenses/by/4.0/), which permits unrestricted use, distribution, and reproduction in any medium, provided you give appropriate credit to the original author(s) and the source, provide a link to the Creative Commons license, and indicate if changes were made. The Creative Commons Public Domain Dedication waiver (http://creativecommons.org/publicdomain/zero/1.0/) applies to the data made available in this article, unless otherwise stated. 


\section{Background}

According to the World Health Organization (WHO), 35\% of women worldwide have experienced either sexual or physical violence at some point in their lifetime [1]. Intimate partner violence (IPV), which includes physical, sexual, and emotional abuse as well as controlling behaviors perpetrated by an intimate partner, is experienced by women globally within every culture, race, ethnicity, and throughout every socioeconomic class [2]. Incidents of violence against women are most commonly perpetrated by male intimate partners or ex-partners [2]. A WHO multi-country study on women's health and domestic violence against women showed that among 24,000 women, a significant number of them experienced IPV - both physical and/or sexual - from their partners. Further, this study confirmed that IPV is a widespread, international issue as data was collected from women all over the world [3].

Individual, relationship, and community factors can increase the likelihood of a woman experiencing IPV [4-7]. Additionally, women may choose to stay in abusive relationships due to their economic situation, circumstances regarding their children, and other reasons that may not be conducive to leaving [8]. When women are subjected to IPV, unintended pregnancies, STIs, and other diseases and complications may occur [4]. Women subjected to IPV are not the only individuals negatively impacted from the violence. IPV can hinder the health and wellbeing of children and infants within the family $[5,6]$.

Most neonatal, infant, and child deaths occur in lowand middle-income countries (LMICs), where incidence of IPV is highest in the world [7]. Research on neonatal, infant, and child mortality and its respective causes are pertinent to decreasing mortality rates across the globe. In 2015, 4.5 million infants died within their first year of life, with sub-Saharan Africa having the highest infant mortality rate of 55 per 1000 live births [8].

The United Nation's Sustainable Development Platform aims to collectively bring prosperity to all countries partnering for progress by setting 17 goals [9]. Sustainable Development Goal 5 aims to achieve gender equality while empowering all women and girls. By 2030, the hope is to eliminate all forms of discrimination and violence towards women as well as harmful practices of gender mutilation and forced marriages. Additionally, there should be equal opportunities for all women, access to quality sexual and reproductive healthcare, and adoption of sound government policies that will protect these rights [10]. Since 1999, The United Nations has successfully reduced infant mortality by more than $50 \%$; yet IPV and neonatal, infant, and child mortality remain an active issue in the field of public health [9].

Burundi, Kenya, Rwanda, Tanzania, and Uganda are not immune to these statistics (see Table 1), although the countries have made progress in decreasing the mortality rates of neonates, infants, and children over time $[11,12]$. Known factors contributing to high mortality within sub-Saharan Africa include: high population areas that put a strain on services, birth asphyxia, infections, AIDS, pneumonia, genocide, and diarrheal diseases [11, 12]. The health and well-being of the mother is a key component in the health and well-being of her children $[12,13]$. Due to the impact and role a mother has in the development of her children, it is clear how IPV negatively affects the health of infants and children as well as impacting mortality among this age group. Our study, therefore, aims to examine associations between IPV against women and death rates among their neonates, infants, and children in East Africa.

\section{Methods}

This analysis was conducted using data from the Demographic and Health Survey (DHS), a series of nationally representative household studies being conducted in more than 90 countries by ICF Macro/MEASURE DHS with funding from the United States Agency for International Development [14]. DHS surveys collect household and individual data using standardized questionnaires and modules. This analysis uses DHS data collected from women of reproductive age (15-49 years) in Burundi (data collected in 2016-2017), Kenya (2014), Rwanda (20142015), Tanzania (2017), and Uganda (2016). Our data were drawn from the domestic violence module, which is administered to a subsample of DHS survey respondents.

Table 1 Country statistics

\begin{tabular}{lllllllll}
\hline Country & Year & Population (no.) & $\begin{array}{l}\text { GDP per } \\
\text { Capita (USD) }\end{array}$ & $\begin{array}{l}\text { Crude Birth } \\
\text { Rate per 1000 }\end{array}$ & $\begin{array}{l}\text { Maternal } \\
\text { Mortality } \\
\text { per 100,000 } \\
\text { Live Births }\end{array}$ & $\begin{array}{l}\text { Under-5 } \\
\text { Mortality } \\
\text { per 1000 } \\
\text { Live Births }\end{array}$ & $\begin{array}{l}\text { Neonatal Mortality } \\
\text { per 1000 Live Births }\end{array}$ & $\begin{array}{l}\text { Sexual Violence } \\
15-49 \text { Years }\end{array}$ \\
\hline Burundi & $2015-2016$ & $10.8 \mathrm{M}$ & 285.7 & 34 & 334 & 71.7 & 24.2 & $23 \%$ \\
Kenya & $2014-2015$ & $43 \mathrm{M}$ & 1143.1 & 30.5 & 362 & 52 & 22 & $14 \%$ \\
Rwanda & $2015-2016$ & $10.5 \mathrm{M}$ & 719 & 32.6 & 210 & 50 & 20 & $22.4 \%$ \\
Tanzania & $2015-2016$ & $50.1 \mathrm{M}$ & 867 & 37.2 & 398 & 67 & 25 & $17 \%$ \\
Uganda & $2015-2016$ & $41 \mathrm{M}$ & 580.4 & 42.1 & 432 & 64 & 27 & $39 \%$ \\
\hline
\end{tabular}


All countries included in our analysis had included the questions from the domestic violence module.

\section{Sample size and sampling techniques}

The DHS survey in the five East African countries was conducted with nationally representative samples of households in each (Kenya, 36,430; Tanzania, 12,563; Uganda, 19,588; Rwanda, 12,699; and Burundi, 8596). The sample for this analysis, based on the response to our IPV outcome variable, was 11,512 women of reproductive age (15-49 years) as follows: Kenya 2432, Tanzania 2001, Uganda 3579, Rwanda 1479, and Burundi 2021.

\section{Conceptual framework and study variables}

The study is organized by a conceptual framework which presents sociological and biological variables hierarchically into distal and proximate determinants of child survival in developing countries [15]. A literature search conducted using Google Scholar, PubMed, and Hinari was used to identify variables addressing the relationship between IPV and neonatal, infant, and child mortality in sub-Saharan Africa. Distal variables include a variety of socioeconomic determinants and community factors. Proximate factors include health status factors of both mother and neonate, infant, or child, including levels of IPV that contribute to infant, child, and neonatal mortality, as indicated in Fig. 1 and Table 2.

Neonatal mortality (NM) is the death of a neonate between birth and one month of life. Infant mortality (IM) is the death of an infant before his/her first birthday. Child mortality (under-five mortality/UM) is the death of infants and children under the age of five. These three types of mortality serve as the outcome variables in this study and were binary in nature. Neonatal death will be regarded as present $(1=$ if death occurs in the specified age period) or absent $(0=$ if the newborn/infant/child is alive in the specified age period).

The DHS instrument includes questions that ask evermarried women whether their current or most recent (if

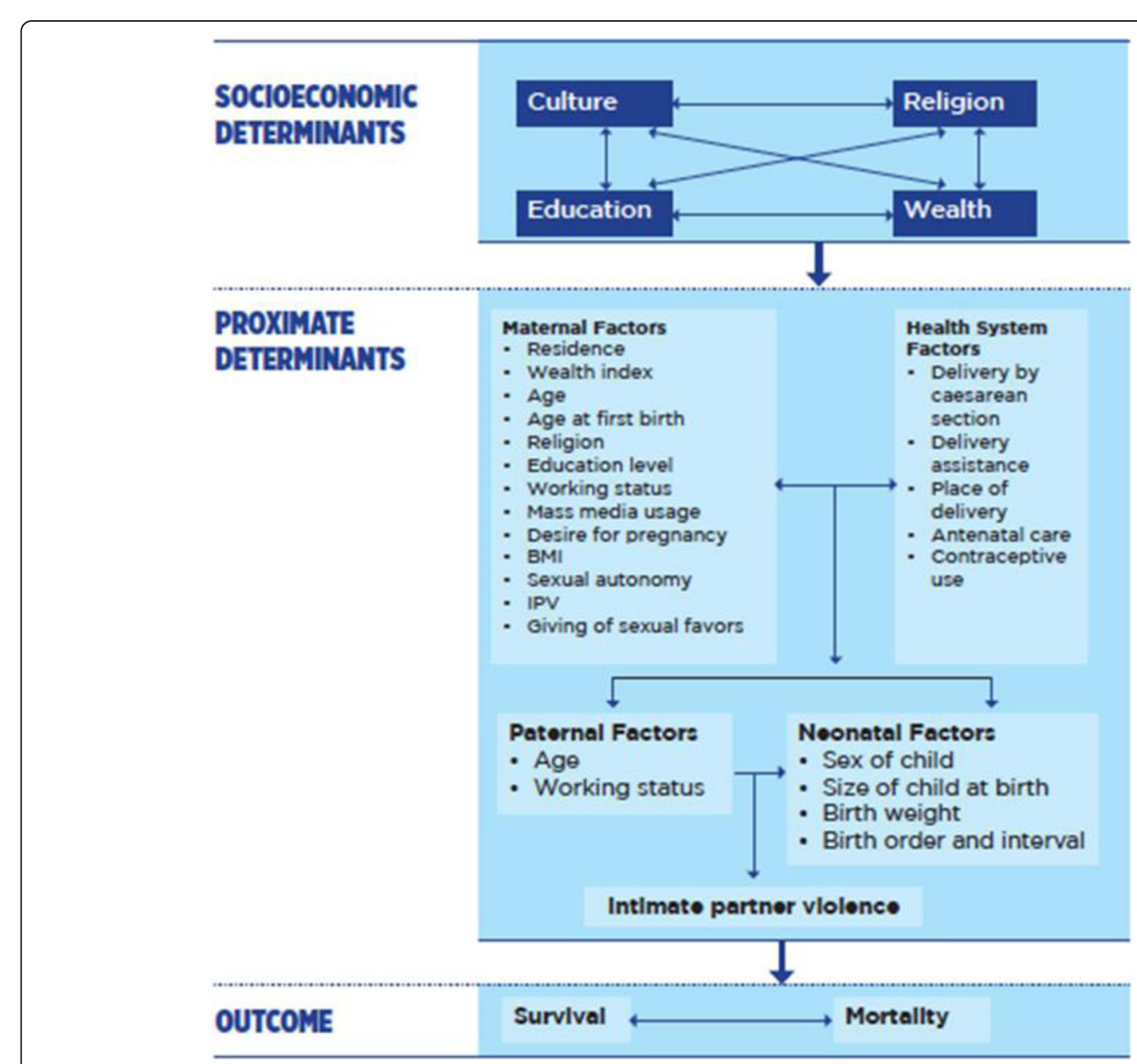

Fig. 1 Conceptual Framework on Intimate Partner Violence 
Table 2 Variable description and categorization

\begin{tabular}{|c|c|}
\hline Variables & Description and Categorization \\
\hline \multicolumn{2}{|l|}{ Socioeconomic Determinants } \\
\hline Residence & Area of residence ( 1 = Rural; 2 = Urban) \\
\hline Wealth index & Household wealth index ( 1 = Poor; 2 = Middle; 3 = Rich) \\
\hline Mother's age & Age of mother $(1=<20 ; 2=20-29 ; 3=30-49)$ \\
\hline Mother's age at first birth & Age of mother at first birth $(1=<20 ; 2=20-29,3=30-49)$ \\
\hline Mother's religion & $\begin{array}{l}\text { Mother's religion ( } 1=\text { Roman Catholic; } 2=\text { Protestant } / \text { Other } \\
\text { Christian; } 3=\text { Muslim; } 4=\text { No religion) }\end{array}$ \\
\hline Mother's education level & $\begin{array}{l}\text { Mother's education level }(1=\text { No education; } 2=\text { Primary; } \\
3=\text { Secondary; } 4=\text { Higher })\end{array}$ \\
\hline Mother's working status & Mother's working status ( 1 = No; 2 = Yes) \\
\hline Mother's mass media usage & Mother's mass media usage ( $1=$ Yes; $2=\mathrm{No})$ \\
\hline \multicolumn{2}{|l|}{ Maternal Factors } \\
\hline Desire for pregnancy & $\begin{array}{l}\text { Mother's desire to have a baby }(1=\text { Then; } 2=\text { Later; } \\
3=\text { No more) }\end{array}$ \\
\hline BMI $\left(\mathrm{kg} / \mathrm{m}^{2}\right)$ & Mother's body mass index $(1=<18.5 ; 2=>=18.5)$ : \\
\hline Sexual autonomy & $\begin{array}{l}\text { Mother's consent to engage in sexual activities } \\
(1=\mathrm{No} ; 2=\mathrm{Yes})\end{array}$ \\
\hline Mother experienced IPV & Mother experienced IPV (1 = No; 2 = Yes) \\
\hline Mother giving sexual favors & $\begin{array}{l}\text { Mother seeking to provide sexual favors for economic gain } \\
(1=\mathrm{No} ; 2=\text { Yes })\end{array}$ \\
\hline \multicolumn{2}{|l|}{ Health System Factors } \\
\hline Delivery by Caesarean section & Delivery by Caesarean section ( 1 = No; 2 = Yes) \\
\hline Delivery assistance & $\begin{array}{l}\text { Professional assistance during birth }(1=\text { Non-health } \\
\text { professional; } 2=\text { Health professional) }\end{array}$ \\
\hline Place of delivery & Place of delivery ( 1 = Home delivery; 2 = Hospital/Other) \\
\hline Antenatal care & $\begin{array}{l}\text { Antenatal care received by mother during pregnancy } \\
(1=\mathrm{No} ; 2=\text { Yes })\end{array}$ \\
\hline Contraceptive use at last sexual encounter & Mother's contraceptive use (1 = No; $2=$ Yes) \\
\hline \multicolumn{2}{|l|}{ Paternal Factors } \\
\hline Husband/partner's age & Age of husband $(1=<29 ; 2=30-39 ; 3=40-49 ; 4=50$ plus $)$ \\
\hline Father's working status & Father's working status ( $1=\mathrm{No} ; 2=$ Yes) \\
\hline \multicolumn{2}{|l|}{ Neonatal Factors } \\
\hline Sex of child & Sex of child ( 1 = Male; 2 = Female) \\
\hline Size of child at birth & $\begin{array}{l}\text { Size of child at birth ( } 1=\text { Average or larger; } 2=\text { Small or very } \\
\text { small; } 3=\text { Missing) }\end{array}$ \\
\hline Birth weight (g) & $\begin{array}{l}\text { Weight of child at birth }(1=<2500 ; 2=2500-3500 ; 3=>3500 \text {; } \\
4=\text { Not weighed; } 5=\text { Don't know })\end{array}$ \\
\hline Birth order and interval & $\begin{array}{l}\text { Birth order and birth interval }(1=2 \text { nd } / 3 \text { rd child, }>2 \text { years; } \\
2=1 \text { st child; } 3=2 \text { nd } / 3 \text { rd child, }<=2 \text { years; } 4=4 \text { th } / \text { higher child, } \\
>2 \text { years; } 5=4 \text { th/higher child, }<=2 \text { years })\end{array}$ \\
\hline
\end{tabular}

divorced, separated, or widowed) partner has ever perpetuated a series of behavioral items. The variable of interest was IPV, classified as a composite variable consisting of emotional, physical, and sexual violence. The composite variable took a binary form such that answering "Yes" to any of the forms of violence was regarded as present ( $1=$ if respondent answered "Yes" to experiencing any of the forms of violence) or absent $(0=$ if respondent answered "No" to experiencing any of the forms of violence). Physical violence was described to respondents as when their (last) partner decided to: Push you, shake you, throw something at you, slap you, punch you, kick you, drag you, "beat you up", try to choke or strangle you, burn you on purpose, threaten you with a knife or any other weapon, or attack you with a knife or any other weapon. Emotional violence was explained to 
respondents in the following way: Does/did he ever say or do something to humiliate you in front of others? Does he threaten you or someone close to you with harm? Does he become jealous or angry if you talk/ talked to other men? Sexual violence was described to respondents as your partner ever having: Forced you to have sexual intercourse when you did not want to, forced you to perform any sexual acts you did not want to, or forced you to have sex with another person [16].

\section{Other variables}

DHS variables of age, marital status, educational level, religion, type and place of residence, occupational status, and wealth index were also used in our analysis. Additional sexual and behavioral variables for women were used and are indicated in Table 2.

Pre-calculated sampling weights which account for both sampling probability and non-response included in the datasets were applied. We also used the complex survey (svy) commands available within STATA 14 to account for clustered sampling design and to estimate robust standard errors as the basis for the 95\% confidence intervals. Analysis involved descriptive statistics, specifically frequencies and percentages for all hypothesized correlates of IPV, and inferential statistics using Chi-square tests to assess bivariate association among IPV and covariates. Logistic regression analyses were used to assess for associations of the covariates to neonatal, infant, and child mortality reporting the odds ratios (OR) and respective 95\% confidence intervals. Statistical levels of significance were evaluated at $5 \%$ as reported in the following sections.

\section{Results}

Table 3 presents the estimated mortality rates (per 100) for neonates (NMR), infants (IMR), and children under five (UMR) among the five combined countries and further stratified by the characteristics of the sampled women listed in Table 2. The rates are presented with 95\% probability confidence intervals. Most estimated rates for categories of a given demographic variable fall within the confidence intervals of the other categories, indicating no significant difference. This section highlights significant differences between categories of demographic variables.

Our results indicate that the birth weight of neonates, infants, and children under five was a significant factor in child mortality - especially considering that small or very small babies had higher mortality rates (NMR: 4.8 vs. 2.1 ; IMR: 6.4 vs. 3.4 ; UMR: 7.6 vs. 4.4 ). Additionally, the mortality rates of offspring of women who did not receive antenatal care was higher than those who received antenatal care (NMR: 4.9 vs. 1.7; IMR: 6.6 vs. 2.6; UMR: 7.4 vs. 3.1). It should be noted that there was a small group of women in this category causing the confidence intervals to be larger. The rates of neonatal mortality were higher for babies delivered by Caesarean section (NMR: 3.7 vs. 2.5), and the estimated infant and under five rates for Caesarean babies were also higher but within confidence intervals of the non-Caesarean delivery estimates. Furthermore, women who reported IPV showed higher rates of child mortality - most notably under five mortality rates were significantly higher (5.4 vs. 4.6).

\section{Characteristics of women who experience IPV: bivariate comparisons}

Tests for independence evidenced that socioeconomic indicators like area of residence, wealth index, age of mother/husband, religion, level of education, employment status, and mass media usage were significantly associated with IPV. Women who had a body mass index (BMI) lower than $18.5 \mathrm{~kg} / \mathrm{m}^{2}$ and desired pregnancy later than at the time of interview were associated with a lower proportion of experiencing IPV $(p<0.001)$. Although the association between sex of the child and IPV was not significant, perceived and actual birth weight were significantly associated with IPV. More so, IPV was significantly associated with child birth order, number, and interval $(p<0.001)$. However, there was no significant association between neonatal, infant, and under-five mortality between the outcome categories of IPV. Women who delivered in hospitals via Caesarean section received professional assistance during birth, and using contraceptives was associated with lower proportions of IPV $(p<0.001)$. IPV was also significantly associated with antenatal care and sexual autonomy $(p<0.001)$. Mothers receiving money/gifts/favors in exchange for sex were not significantly associated with IPV. These findings are presented in Table 4.

Women who are between ages 20 and 29, who reside in rural areas, who do not use mass media at all, who had a BMI of greater than or equal to $18.5 \mathrm{~kg} / \mathrm{m}^{2}$, and who were not aware of the birthweight of their babies, were significantly more likely to experience infant and under-five mortality among their children. Additionally, children were more at risk of dying as infants and prior to the age of five if their mothers experienced IPV. However, antenatal care and contraceptive use decreased the likelihood of infant and children under five deaths. Results from both the unadjusted and adjusted regression analyses are presented in Table 5.

\section{Discussion}

The current study examined the association between IPV among women and rates of mortality among their neonates, infants, and children less than five years of age in East Africa using DHS, a nationally representative 
Table 3 Neonatal, infant, and under-five mortality rates in East Africa (per 100 births) by demographic characteristics of mothers

\begin{tabular}{|c|c|c|c|}
\hline \multirow[t]{2}{*}{ Variable } & \multicolumn{3}{|c|}{$\begin{array}{l}\text { East Africa } \\
\text { (Kenya } n=2432 \text {, Uganda } n=3579 \text {, } \\
\text { Tanzania } n=2001 \text {, Rwanda } n=1479 \text {, } \\
\text { Burundi } n=2021 \text {, Total } n=11,512 \text { ) }\end{array}$} \\
\hline & NMR (95\% Cl) & IMR $(95 \% \mathrm{Cl})$ & UMR $(95 \% \mathrm{Cl})$ \\
\hline \multicolumn{4}{|c|}{ Intimate Partner Violence } \\
\hline \multicolumn{4}{|c|}{ Mother Experienced IPV } \\
\hline No & $2.4(2.2-2.7)$ & $\begin{array}{l}3.7(3.4-4) \\
4.6(4.3-5)\end{array}$ & \\
\hline Yes & $2.9(2.6-3.1)$ & $\begin{array}{l}4.2(3.9-4.5)^{*} \\
5.4(5.1-5.7)^{*}\end{array}$ & \\
\hline \multicolumn{4}{|l|}{ Socioeconomic Factors } \\
\hline \multicolumn{4}{|l|}{ Residential area } \\
\hline Rural & $3(2.6-3.4)$ & $4.2(3.7-4.7)^{*}$ & $5(4.5-5.6)^{* *}$ \\
\hline Urban & $2.5(2.3-2.6)$ & $3.8(3.6-4)$ & $4.9(4.7-5.1)$ \\
\hline \multicolumn{4}{|l|}{ Wealth index } \\
\hline Poor & $2.5(2.3-2.7)$ & $4(3.7-4.3)$ & $5.3(5-5.6)$ \\
\hline Middle & $2.5(2.2-2.8)$ & $3.7(3.3-4.1)$ & $4.6(4.2-5)$ \\
\hline Rich & $2.8(2.5-3.1)$ & $3.9(3.6-4.3)$ & $4.7(4.3-5.1)$ \\
\hline \multicolumn{4}{|l|}{ Mother's age } \\
\hline$<20$ years & $3.8(3.1-4.7)$ & $4.9(4.1-5.9)$ & $5.6(4.7-6.6)$ \\
\hline 20-29 years & $2.5(2.3-2.7)$ & $3.8(3.6-4.1)$ & $4.9(4.6-5.2)^{*}$ \\
\hline $30-49$ years & $2.8(2.5-3.1)$ & $3.9(3.7-4.2)$ & $4.9(4.6-5.3)$ \\
\hline \multicolumn{4}{|c|}{ Mother's age at first birth } \\
\hline$<20$ years & $2.5(2.3-2.7)$ & $3.9(3.7-4.2)$ & $5.1(4.8-5.4)$ \\
\hline 20-29 years & $2.6(2.4-2.9)^{*}$ & $3.9(3.6-4.2)$ & $4.7(4.4-5)$ \\
\hline 30-49 years & $3.2(1.8-5.5)$ & $4.7(3.1-7.1)$ & $5.5(3.8-7.9)$ \\
\hline \multicolumn{4}{|l|}{ Mother's religion } \\
\hline Roman Catholic & $2.7(2.4-3)$ & $4.2(3.8-4.5)$ & $5.2(4.8-5.7)$ \\
\hline Protestant & $2.4(2.2-2.7)$ & $3.7(3.4-4)$ & $4.6(4.3-4.9)$ \\
\hline Muslim & $2.9(2.4-3.6)$ & $4(3.4-4.8)$ & $4.9(4.2-5.7)$ \\
\hline No religion & $2.4(1.9-3)$ & $3.8(3.2-4.5)$ & $5.1(4.4-5.9)$ \\
\hline \multicolumn{4}{|c|}{ Mother's education level } \\
\hline No education & $2.5(2.2-2.8)$ & $4.1(3.8-4.6)$ & $5.7(5.2-6.2)$ \\
\hline Primary & $2.6(2.5-2.8)$ & $4(3.8-4.3)$ & $5(5.8-5.3)$ \\
\hline Secondary & $2.5(2.1-2.9)$ & $3.5(3-4)$ & $4(3.5-4.6)$ \\
\hline Higher & $2.8(1.8-4.5)$ & $3.5(2.4-5.2)$ & $3.7(2.5-5.3)$ \\
\hline \multicolumn{4}{|c|}{ Mother's working status } \\
\hline No & $2.6(2.3-3.1)$ & $3.8(3.4-4.3)$ & $4.8(4.3-5.3)$ \\
\hline Yes & $2.6(2.5-2.8)$ & $4(3.8-4.3)$ & $5.1(4.8-5.4)$ \\
\hline \multicolumn{4}{|c|}{ Mother's mass media usage } \\
\hline Yes & $2.5(2.2-2.8)$ & $3.9(3.6-4.3)$ & $5.2(4.8-5.6)$ \\
\hline No & $2.6(2.5-2.8)$ & $3.9(3.7-4.2)$ & $4.8(4.6-5.1)$ \\
\hline \multicolumn{4}{|l|}{ Maternal Factors } \\
\hline \multicolumn{4}{|l|}{ Desire for pregnancy } \\
\hline Then & $2.8(2.5-3)$ & $4.2(3.9-4.5)$ & $5.3(5-5.6)$ \\
\hline Later & $2.3(2-2.6)^{*}$ & $3.5(3.1-3.8)$ & $4.4(4-4.9)^{*}$ \\
\hline
\end{tabular}


Table 3 Neonatal, infant, and under-five mortality rates in East Africa (per 100 births) by demographic characteristics of mothers (Continued)

\begin{tabular}{|c|c|c|c|}
\hline \multirow[t]{2}{*}{ Variable } & \multicolumn{3}{|c|}{$\begin{array}{l}\text { East Africa } \\
\text { (Kenya } n=2432, \text { Uganda } n=3579 \\
\text { Tanzania } n=2001 \text {, Rwanda } n=1479 \text {, } \\
\text { Burundi } n=2021 \text {, Total } n=11,512 \text { ) }\end{array}$} \\
\hline & NMR (95\% Cl) & IMR (95\% Cl) & UMR $(95 \% \mathrm{Cl})$ \\
\hline No more & $2.7(2.2-3.4)$ & $3.8(3.2-4.6)$ & $4.5(3.8-5.3)$ \\
\hline \multicolumn{4}{|l|}{ Mother's BMI } \\
\hline$<18.5$ & $1.7(1.3-2.3)$ & $3.1(2.4-3.9)$ & $4.1(3.4-5)$ \\
\hline$>=18.5$ & $2.8(2.6-3.1)$ & $4.1(3.9-4.4)^{*}$ & $5.2(4.9-5.5)^{*}$ \\
\hline \multicolumn{4}{|l|}{ Sexual autonomy } \\
\hline No & $3.1(2.7-3.6)$ & $4.6(4.1-5.1)$ & $5.7(5.1-6.2)$ \\
\hline Yes & $2.5(2.3-2.7)$ & $3.8(3.5-4)$ & $4.8(4.5-5)$ \\
\hline \multicolumn{4}{|l|}{ Mother giving sexual favors } \\
\hline No & $2.6(2.1-3.2)$ & $3.9(3.3-4.6)$ & $4.6(4-5.3)$ \\
\hline Yes & $3.2(1.3-7.5)$ & $5.3(2.1-12.9)$ & $5.6(2.3-13)$ \\
\hline \multicolumn{4}{|l|}{ Health System Factors } \\
\hline \multicolumn{4}{|c|}{ Delivery by Caesarean section } \\
\hline No & $2.5(2.4-2.7)$ & $3.8(3.7-4.1)$ & $4.9(4.7-5.1)$ \\
\hline Yes & $3.7(2.9-4.7)^{*}$ & $4.8(3.9-5.9)^{*}$ & $5.7(4.8-6.8)^{*}$ \\
\hline \multicolumn{4}{|l|}{ Delivery assistance } \\
\hline Non-health professional & $2.7(2.4-3)$ & $4(3.7-4.4)$ & $5.1(4.7-5.6)$ \\
\hline Health professional & $2.5(2.3-2.7)$ & $3.7(3.5-4)$ & $4.7(4.4-5)$ \\
\hline \multicolumn{4}{|l|}{ Place of delivery } \\
\hline Home delivery & $2.6(2.3-2.9)$ & $4(3.7-4.4)$ & $5.2(4.8-5.6)$ \\
\hline Hospital/other & $2.6(2.4-2.8)$ & $3.8(3.6-4.1)$ & $4.8(4.5-5)$ \\
\hline \multicolumn{4}{|l|}{ Antenatal care } \\
\hline No & $4.9(3.6-6.6)$ & $6.6(5.1-8.5)$ & $7.4(5.8-9.3)$ \\
\hline Yes & $1.7(1.5-1.8)$ & $2.6(2.4-2.7)$ & $3.1(2.9-3.3)$ \\
\hline \multicolumn{4}{|l|}{ Contraceptive use } \\
\hline Not using & $3(2.8-3.2)$ & $4.6(4.3-4.8)$ & $5.8(5.6-6.2)$ \\
\hline Using & $2.1(1.8-2.3)^{*}$ & $3(2.8-3.3)^{*}$ & $3.7(3.4-4)^{*}$ \\
\hline \multicolumn{4}{|l|}{ Paternal Factors } \\
\hline \multicolumn{4}{|l|}{ Husband/partner's age } \\
\hline$<29$ years & $2.9(2.5-3.3)$ & $4.1(3.7-4.6)$ & $5.3(4.8-5.8)$ \\
\hline 30-39 years & $2.3(2.1-2.6)$ & $3.7(3.4-4)$ & $4.6(4.2-5)$ \\
\hline $40-49$ years & $2.8(2.4-3.2)$ & $4(3.6-4.5)$ & $5(4.5-5.5)$ \\
\hline 50 plus years & $2.9(2.3-3.7)$ & $4.3(3.5-5.2)$ & $6(5.1-7)$ \\
\hline \multicolumn{4}{|l|}{ Father's working status } \\
\hline No & $3.4(2.3-5)$ & $4.9(3.6-6.7)$ & $6.5(5-8.3)$ \\
\hline Yes & $2.6(2.4-2.8)$ & $3.9(3.7-4.1)$ & $4.9(4.7-5.2)$ \\
\hline \multicolumn{4}{|l|}{ Neonatal Factors } \\
\hline \multicolumn{4}{|l|}{ Sex of child } \\
\hline Male & $2.9(2.7-3.1)$ & $4.3(4-4.6)$ & $5.3(5.1-5.7)$ \\
\hline Female & $2.3(2.1-2.5)$ & $3.5(3.3-3.8)$ & $4.5(4.2-4.8)$ \\
\hline
\end{tabular}


Table 3 Neonatal, infant, and under-five mortality rates in East Africa (per 100 births) by demographic characteristics of mothers (Continued)

\begin{tabular}{|c|c|c|c|}
\hline \multirow[t]{2}{*}{ Variable } & \multicolumn{3}{|c|}{$\begin{array}{l}\text { East Africa } \\
\text { (Kenya } n=2432 \text {, Uganda } n=3579 \\
\text { Tanzania } n=2001 \text {, Rwanda } n=1479 \text {, } \\
\text { Burundi } n=2021 \text {, Total } n=11,512 \text { ) }\end{array}$} \\
\hline & NMR (95\% Cl) & $\operatorname{IMR}(95 \% \mathrm{Cl})$ & UMR (95\% Cl) \\
\hline \multicolumn{4}{|l|}{ Size of child at birth } \\
\hline Average or larger & $2.1(1.9-2.3)$ & $3.4(3.2-3.6)$ & $4.4(4.2-4.6)$ \\
\hline Small or very small & $4.8(4.2-5.3)^{*}$ & $6.4(5.8-7.1)^{*}$ & $7.6(7-8.3)^{*}$ \\
\hline Don't know & $12.2(9.3-15.9)^{*}$ & $13.1(10.1-16.8)^{*}$ & $14.6(11.6-18.2)^{*}$ \\
\hline \multicolumn{4}{|l|}{ Birth weight (g) } \\
\hline$<2500$ & $6.5(5.5-7.5)$ & $8.9(7.7-10.1)$ & $10.2(9-11.6)$ \\
\hline $2500-3500$ & $1.5(1.4-1.7)^{*}$ & $2.7(2.5-3)^{*}$ & $3.6(3.4-3.9)^{*}$ \\
\hline$>3500$ & $1.9(1.6-2.3)^{*}$ & $3.1(2.7-3.6)$ & $4.2(3.7-4.7)$ \\
\hline Not weighed & $3.8(3.4-4.2)$ & $5.1(4.7-5.6)$ & $6.3(5.9-6.8)$ \\
\hline Don't know & $16.3(12.8-20.5)^{*}$ & $17.8(14.2-22.1)$ & 19.3(15.5-23.6) \\
\hline \multicolumn{4}{|l|}{ Birth order and interval } \\
\hline $2 \mathrm{nd} / 3 \mathrm{rd}$ child, $>2$ years & $2(1.7-2.2)$ & $3.2(2.9-3.5)$ & $4.1(3.8-4.5)$ \\
\hline 1st child & $3.3(2.9-3.7)$ & $4.4(4-4.9)$ & $5.4(5-5.9)$ \\
\hline $2 \mathrm{nd} / 3 \mathrm{rd}$ child, $\leq 2$ years & $2.6(2.1-3.1)$ & $4(3.4-4.6)$ & $5.2(4.6-5.9)$ \\
\hline 4th/higher child, $>2$ years & $2.3(2.1-2.6)$ & $3.6(3.2-3.9)$ & $4.5(4.2-4.9)$ \\
\hline 4th/higher child, $\leq 2$ years & $3.7(3.2-4.3)^{*}$ & $6(5.3-6.8)^{*}$ & $7.3(6.5-8.1)^{*}$ \\
\hline
\end{tabular}

Two asterisks $\left(^{* *}\right)$ denotes the $p$-value is $<0.001$, and one asterisk $\left(^{*}\right)$ denotes the $p$-value is $<0.05$

dataset. In resource-limited countries, such as Kenya, Burundi, Tanzania, Uganda and Rwanda, high mortality rates before a child reaches the age of five years are common [12]. Based on the adjusted model, our study findings found that women exposed to IPV were more likely to lose their children. Study findings provide evidence for an association showing that children born to women who are IPV survivors were significantly more likely to die as newborns, infants, and children under five. These findings are consistent with those of previous studies in Bangladesh [16], India [17], and Kenya, Egypt, Malawi, Honduras, \& Rwanda [18]. In essence, we concur that the high infant and child mortality rates among women experiencing IPV could be influenced by the negative impact on their mental and physical health, which is likely to affect their pregnancy and subsequent caregiving [19].

There is evidence on the negative effects of IPV during pregnancy. A multi-country study by WHO involving 10 countries indicated a prevalence of $4-12 \%$ in most countries with 28\% reported in Peru [2]. Another study involving 19 countries reported a higher prevalence of IPV during pregnancy in African and Latin American countries with highest prevalence of $13.5 \%$ with most victims being in the younger age groups (15-35 years) [19]. Studies indicate that IPV during pregnancy can result in antepartum hospitalization, pregnancy complications, low birth weight, and even infant death [20]. Further studies indicate that IPV during pregnancy is associated with miscarriage, late entry into prenatal care, stillbirth, premature labor, and fetal injury [2]. These findings support the negative impact of IPV on the health of the mother, which effects far more than just physical health and wellbeing. IPV affects the social, mental, and psychological well-being of the mother due to the traumatic nature of the violence they experience. This, therefore, affects their capacity to care for their child and contributes to underutilization of maternal health services [16]. Given the role that mothers play in a child's life, their health status during and after pregnancy is a direct predictor of an infant and child's health outcomes.

Violence against women can be linked to mortality rates among infants and children via various mechanisms. For instance, while socioeconomic indicators like area of residence, wealth index, age of mother/husband, religion, level of education, employment status, and mass media usage were significantly associated with IPV in the study, they can also be considered underlying factors in infant and child mortality. From these findings, the influence of social determinants of health in the relationship between IPV and child mortality is cause for further investigation. Interventions should strive to focus on addressing IPV at multiple levels and not just individual levels. The 
Table 4 Characteristics of women who experience intimate partner violence: bivariate comparisons

\begin{tabular}{|c|c|c|c|}
\hline \multirow[t]{2}{*}{ Variable } & \multicolumn{2}{|c|}{ Intimate Partner Violence (IPV) } & \multirow{2}{*}{$\begin{array}{l}\text { Pearson chi2 } \\
\text { ( } p \text { value) }\end{array}$} \\
\hline & $\begin{array}{l}\text { No, } \mathrm{n}(\%) \\
(n=4780)\end{array}$ & $\begin{array}{l}\text { Yes, n (\%) } \\
(n=5390)\end{array}$ & \\
\hline \multicolumn{4}{|l|}{ Socioeconomic Determinants } \\
\hline \multicolumn{4}{|l|}{ Residential area } \\
\hline Urban & 1864 (39) & $1471(27.7)$ & $144.836(<0.001)^{*}$ \\
\hline Rural & $2916(61)$ & $3838(72.3)$ & \\
\hline Wealth index & & & $520.722(<0.001)^{*}$ \\
\hline Poor & $2095(43.8)$ & $3404(64.1)$ & \\
\hline Middle & $837(17.5)$ & $878(16.5)$ & \\
\hline Rich & $1848(38.7)$ & $1027(19.3)$ & \\
\hline Mother's age & & & $15.468(<0.001)^{*}$ \\
\hline$<20$ years & $203(4.2)$ & $284(5.3)$ & \\
\hline 20-29 years & $2535(53)$ & $2934(55.3)$ & \\
\hline $30-49$ years & $2042(42.7)$ & $2091(39.4)$ & \\
\hline Mother's age at first birth & & & $85.857(<0.001)^{*}$ \\
\hline$<20$ years & $2561(53.6)$ & $3318(62.5)$ & \\
\hline 20-29 years & $2153(45)$ & $1950(36.7)$ & \\
\hline $30-49$ years & $66(1.4)$ & $41(0.8)$ & \\
\hline Mother's religion & & & $37.736(<0.001)^{*}$ \\
\hline Roman Catholic & 917 (19.2) & $970(18.3)$ & \\
\hline Protestant/Other Christian & $3011(63)$ & $3201(60.3)$ & \\
\hline Muslim & $747(15.6)$ & $916(17.3)$ & \\
\hline No religion & $105(2.2)$ & $220(4.1)$ & \\
\hline Mother's education level & & & $451.636(<0.001)^{*}$ \\
\hline No education & $790(16.5)$ & $1396(26.3)$ & \\
\hline Primary & $2399(50.2)$ & $2964(55.8)$ & \\
\hline Secondary & $1105(23.1)$ & $821(15.5)$ & \\
\hline Higher & $486(10.2)$ & $128(2.4)$ & \\
\hline Mother's working status & & & $4.446(0.035)^{*}$ \\
\hline No & 1695 (35.6) & $1992(37.7)$ & \\
\hline Yes & $3061(64.4)$ & $3296(62.3)$ & \\
\hline Mother's mass media usage & & & $108.929(<0.001)^{*}$ \\
\hline No & $978(20.5)$ & $1566(29.5)$ & \\
\hline Yes & $3802(79.5)$ & $3743(70.5)$ & \\
\hline \multicolumn{4}{|l|}{ Maternal Factors } \\
\hline Desire for pregnancy & & & $16.520(<0.001)^{*}$ \\
\hline Then & $3297(69.2)$ & $3468(65.5)$ & \\
\hline Later & $1035(21.7)$ & $1268(23.9)$ & \\
\hline No more & $430(9)$ & $559(10.6)$ & \\
\hline Mother's BMl & & & $46.377(<0.001)^{*}$ \\
\hline$<18.5$ & $449(9.5)$ & $729(13.9)$ & \\
\hline$>=18.5$ & $4284(90.5)$ & $4519(86.1)$ & \\
\hline Sexual autonomy & & & $28.238(<0.001)^{*}$ \\
\hline No & $1043(22)$ & $1387(26.6)$ & \\
\hline
\end{tabular}


Table 4 Characteristics of women who experience intimate partner violence: bivariate comparisons (Continued)

\begin{tabular}{|c|c|c|c|}
\hline \multirow[t]{2}{*}{ Variable } & \multicolumn{2}{|c|}{ Intimate Partner Violence (IPV) } & \multirow{2}{*}{$\begin{array}{l}\text { Pearson chi2 } \\
\text { ( } p \text { value) }\end{array}$} \\
\hline & $\begin{array}{l}\text { No, } \mathrm{n}(\%) \\
(n=4780)\end{array}$ & $\begin{array}{l}\text { Yes, n (\%) } \\
(n=5390)\end{array}$ & \\
\hline Yes & $3691(78)$ & $3824(73.4)$ & \\
\hline Mother giving sexual favors & & & $0.506(0.477)$ \\
\hline No & $4223(97)$ & $4625(96.8)$ & \\
\hline Yes & $129(3)$ & $154(3.2)$ & \\
\hline \multicolumn{4}{|l|}{ Health System Factors } \\
\hline Delivery by Caesarean section & & & $64.548(<0.001)^{*}$ \\
\hline No & $4360(91.4)$ & $5046(95.3)$ & \\
\hline Yes & $412(8.6)$ & $247(4.7)$ & \\
\hline Delivery assistance & & & $268.011(<0.001)^{*}$ \\
\hline Non-health professional & $1547(33.8)$ & $2537(50.4)$ & \\
\hline Health professional & $3024(66.2)$ & 2499 (49.6) & \\
\hline Place of delivery & & & $264.970(<0.001)^{*}$ \\
\hline Home delivery & $1752(36.8)$ & 2804 (53) & \\
\hline Hospital/other & $3010(63.2)$ & $2489(47)$ & \\
\hline Antenatal care & & & $54.979(<0.001)^{*}$ \\
\hline No & $129(3.7)$ & $281(7.7)$ & \\
\hline Yes & 3398 (96.3) & $3355(92.3)$ & \\
\hline Contraceptive use & & & $109.172(<0.001)^{*}$ \\
\hline Not using & $2257(47.2)$ & 3059 (57.6) & \\
\hline Using & $2523(52.8)$ & $2250(42.4)$ & \\
\hline \multicolumn{4}{|l|}{ Paternal Factors } \\
\hline Husband/partner's age & & & $109.172(<0.001)^{*}$ \\
\hline$<29$ years & $851(21.5)$ & $1111(24.6)$ & \\
\hline 30-39 years & $1892(47.7)$ & $1874(41.5)$ & \\
\hline 40-49 years & $883(22.3)$ & $990(21.9)$ & \\
\hline Father's working status & & & $50.598(<0.001)^{*}$ \\
\hline No & $51(1.2)$ & $129(2.6)$ & \\
\hline Yes & $4362(98.8)$ & $4783(97.4)$ & \\
\hline \multicolumn{4}{|l|}{ Neonatal Factors } \\
\hline Sex of child & & & $1.464(0.226)$ \\
\hline Male & $2449(51.2)$ & $2656(50)$ & \\
\hline Female & $2331(48.8)$ & $2653(50)$ & \\
\hline Size of child at birth & & & $9.008(0.011)^{*}$ \\
\hline Average or larger & 3941 (82.7) & $4326(81.7)$ & \\
\hline Small or very small & $777(16.3)$ & 881 (16.6) & \\
\hline Don't know & $47(1)$ & $88(1.7)$ & \\
\hline Birth weight (Kg) & & & $325.327(<0.001)^{*}$ \\
\hline$<2500$ & $237(5)$ & $208(3.9)$ & \\
\hline $2500-3500$ & $2201(46.3)$ & $1730(32.7)$ & \\
\hline$>3500$ & 799 (16.8) & 736 (13.9) & \\
\hline Not weighed & 1491 (31.3) & $2545(48.1)$ & \\
\hline Don't know & $29(0.6)$ & $69(1.3)$ & \\
\hline
\end{tabular}


Table 4 Characteristics of women who experience intimate partner violence: bivariate comparisons (Continued)

\begin{tabular}{|c|c|c|c|}
\hline \multirow[t]{2}{*}{ Variable } & \multicolumn{2}{|c|}{ Intimate Partner Violence (IPV) } & \multirow{2}{*}{$\begin{array}{l}\text { Pearson chi2 } \\
\text { ( } p \text { value) }\end{array}$} \\
\hline & $\begin{array}{l}\text { No, } \mathrm{n}(\%) \\
(n=4780)\end{array}$ & $\begin{array}{l}\text { Yes, n (\%) } \\
(n=5390)\end{array}$ & \\
\hline Birth order and interval & & & $86.056(<0.001)^{*}$ \\
\hline 2nd/3rd child, $>2$ years & $1513(31.7)$ & $1472(27.7)$ & \\
\hline 1st child & $1201(25.1)$ & $1070(20.2)$ & \\
\hline 2nd/3rd child, $\leq 2$ years & $322(6.7)$ & $490(9.2)$ & \\
\hline 4th/higher child, $>2$ years & $1345(28.1)$ & $1751(33)$ & \\
\hline 4th/higher child, $\leq 2$ years & $399(8.3)$ & $526(9.9)$ & \\
\hline Neonatal mortality & & & $1.437(0.231)$ \\
\hline Alive & 4675 (97.8) & $5173(97.4)$ & \\
\hline Dead & $105(2.2)$ & $136(2.6)$ & \\
\hline Infant mortality & & & $0.099(0.753)$ \\
\hline Alive & $4618(96.6)$ & $5123(96.5)$ & \\
\hline Dead & $162(3.4)$ & $186(3.5)$ & \\
\hline Under-five mortality & & & $0.933(0.334)$ \\
\hline Alive & $4593(96.1)$ & $5081(95.7)$ & \\
\hline Dead & $187(3.9)$ & $228(4.3)$ & \\
\hline
\end{tabular}

One asterisk $\left(^{*}\right)$ denotes the $p$-value is $<0.05$

interconnectedness of the individual and environmental influences warrants an in-depth assessment of this association.

From the results of our study, various socioeconomic and demographic confounding factors revealed a significant influence in the association between IPV and mortality rates among neonates, infants, and children under five, including $\mathrm{BMI}$ and contraceptive use. Current findings revealed that women reporting a low BMI and chose to delay pregnancy were less likely to experience IPV. Furthermore, mortality rates in neonates, infants, and children under five were more likely to be reported among women who had a high BMI (above $18.5 \mathrm{~kg} / \mathrm{m}^{2}$ ) and among those not using contraceptives. It has been shown that women who experienced IPV were more likely to raise children who were underweight and might experience stunted growth; additionally, there is a link between maternal BMI and wasting syndrome in children [21]. Underweight and wasting in children are risk factors for infant and child mortality [22]. In our study, perceived and actual birth weights were significantly associated with IPV. With regard to the association between contraceptive use and IPV, documented research provides conflicting evidence. Consistent with our findings, documented evidence supports that women who suffer from IPV were less likely to use contraceptives compared to women using contraceptives with less likelihood of finding themselves victims of IPV $[23,24]$. We speculate that women who suffer from IPV are likely to use contraceptives because they do not want to raise children under such conditions.

Based on the findings of this study and prior documented research, IPV should be considered an important factor associated with neonatal, infant, and child mortality. It is paramount to provide adequate care to mothers during and after pregnancy to ensure the survival of children. Without such care, IPV can cause mothers to be unsuccessful in carrying a pregnancy to full term or in providing adequate care for their children. Adequate care can be provided by ensuring that mothers have access to maternal health care services and are trained to negotiate for contraceptive use and safer sex in order to enhance sexual autonomy $[25,26]$. WHO has provided guidance on the role of the health system in managing and combatting IPV. Health care providers' responses to those who have been victims of intimate partner violence must be multifaceted with identifying those at risk as only the first step in proper response. As providers screen patients, victims of IPV can explore their options regarding plans for safety and access to support services [27]. Study findings revealed that while IPV was significantly associated with death among neonates, infants, and children, other factors such as antenatal care, sexual autonomy, women delivering in hospitals, and receiving professional assistance during birth were protective factors. Consequently, it can be argued that access to adequate maternal health services can help bridge the gap between IPV and infant and child mortality rates.

\section{Limitations}

The study relied on DHS data that is retrospective in nature. There is a risk of reporting and recall bias due to the reliance on the memory of an event that 
Table 5 Unadjusted and adjusted regression analysis

\begin{tabular}{|c|c|c|c|c|c|c|}
\hline \multirow{3}{*}{ Variable } & \multicolumn{6}{|c|}{ Unadjusted and Adjusted Regression Analysis } \\
\hline & \multicolumn{3}{|c|}{ Unadjusted Analysis } & \multicolumn{3}{|c|}{ Adjusted Analysis } \\
\hline & $\begin{array}{l}\text { Neonatal } \\
\text { Mortality }\end{array}$ & $\begin{array}{l}\text { Infant } \\
\text { Mortality }\end{array}$ & Under-five mortality & $\begin{array}{l}\text { Neonatal } \\
\text { Mortality }\end{array}$ & $\begin{array}{l}\text { Infant } \\
\text { Mortality }\end{array}$ & Under-five mortality \\
\hline \multicolumn{7}{|l|}{ Intimate Partner Violence } \\
\hline \multicolumn{7}{|l|}{ Mother experienced IPV } \\
\hline No & Ref & Ref & Ref & Ref & Ref & Ref \\
\hline Yes & $\begin{array}{l}1.114 \\
(0.744-1.668)\end{array}$ & $\begin{array}{l}1.886 \\
(1.639-1.930)^{*}\end{array}$ & $\begin{array}{l}1.976 \\
(1.727-2.11)^{*}\end{array}$ & $\begin{array}{l}1.340 \\
(1.408-2.222)^{*}\end{array}$ & $\begin{array}{l}1.999 \\
(1.656-2.22)^{*}\end{array}$ & $\begin{array}{l}1.057 \\
(1.01-1.550)^{*}\end{array}$ \\
\hline \multicolumn{7}{|l|}{ Residential area } \\
\hline Urban & Ref & Ref & Ref & & & Ref \\
\hline Rural & $\begin{array}{l}1.860 \\
(1.630-1.951)\end{array}$ & $\begin{array}{l}1.807 \\
(1.640-1.991)^{*}\end{array}$ & $\begin{array}{l}1.826 \\
(1.71-1.916)^{* *}\end{array}$ & & & $\begin{array}{l}1.704 \\
(1.458-1.88)^{* *}\end{array}$ \\
\hline \multicolumn{7}{|l|}{ Wealth index } \\
\hline Poor & Ref & Ref & Ref & Ref & & \\
\hline Middle & $\begin{array}{l}0.84 \\
(0.811-1.531)\end{array}$ & $\begin{array}{l}0.970 \\
(0.729-1.292)\end{array}$ & $\begin{array}{l}0.960 \\
(0.749-1.230)\end{array}$ & $\begin{array}{l}0.965 \\
(0.515-1.806)\end{array}$ & & \\
\hline Rich & $\begin{array}{l}0.806 \\
(0.798-1.532)\end{array}$ & $\begin{array}{l}0.830 \\
(0.879-1.452)\end{array}$ & $\begin{array}{l}0.94 \\
(0.793-1.259)\end{array}$ & $\begin{array}{l}0.493 \\
(0.270-0.902)^{*}\end{array}$ & & \\
\hline \multicolumn{7}{|l|}{ Mother's age } \\
\hline$<20$ years & Ref & Ref & Ref & Ref & & \\
\hline 20-29 years & $\begin{array}{l}1.549 \\
(0.738-3.251)\end{array}$ & $\begin{array}{l}1.584 \\
(0.889-2.822)\end{array}$ & $\begin{array}{l}1.694 \\
(1.002-2.862)^{*}\end{array}$ & $\begin{array}{l}0.799 \\
(0.247-2.585)\end{array}$ & & \\
\hline $30-49$ years & $\begin{array}{l}1.684 \\
(0.806-3.516)\end{array}$ & $\begin{array}{l}1.551 \\
(0.884-2.721)\end{array}$ & $\begin{array}{l}1.654 \\
(0.991-2.763)\end{array}$ & $\begin{array}{l}1.157 \\
(0.359-3.735)\end{array}$ & & \\
\hline \multicolumn{7}{|l|}{ Mother's age at first birth } \\
\hline$<20$ years & Ref & Ref & Ref & & & \\
\hline 20-29 years & $\begin{array}{l}1.321 \\
(1.001-1.745)^{*}\end{array}$ & $\begin{array}{l}1.092 \\
(0.866-1.377)\end{array}$ & $\begin{array}{l}1.002 \\
(0.812-1.236)\end{array}$ & & & \\
\hline $30-49$ years & $\begin{array}{l}1.902 \\
(0.495-7.305)\end{array}$ & $\begin{array}{l}1.481 \\
(0.482-4.551)\end{array}$ & $\begin{array}{l}1.275 \\
(0.445-3.656)\end{array}$ & & & \\
\hline \multicolumn{7}{|l|}{ Mother's religion } \\
\hline Roman Catholic & Ref & Ref & Ref & & & \\
\hline Protestant/Other Christian & $\begin{array}{l}1.000 \\
(0.711-1.408)\end{array}$ & $\begin{array}{l}1.057 \\
(0.790-1.413)\end{array}$ & $\begin{array}{l}1.095 \\
(0.831-1.444)\end{array}$ & & & \\
\hline Muslim & $\begin{array}{l}1.223 \\
(0.783-1.910)\end{array}$ & $\begin{array}{l}1.133 \\
(0.752-1.709)\end{array}$ & $\begin{array}{l}1.124 \\
(0.765-1.650)\end{array}$ & & & \\
\hline No religion & $\begin{array}{l}1.189 \\
(0.676-2.090)\end{array}$ & $\begin{array}{l}0.962 \\
(0.580-1.594)\end{array}$ & $\begin{array}{l}1.031 \\
(0.670-1.586)\end{array}$ & & & \\
\hline \multicolumn{7}{|l|}{ Mother's education level } \\
\hline No education & Ref & Ref & Ref & & & \\
\hline Primary & $\begin{array}{l}1.016 \\
(0.748-1.382)\end{array}$ & $\begin{array}{l}1.159 \\
(0.884-1.519)\end{array}$ & $\begin{array}{l}1.212 \\
(0.949-1.547)\end{array}$ & & & \\
\hline Secondary & $\begin{array}{l}0.826 \\
(0.511-1.333)\end{array}$ & $\begin{array}{l}1.117 \\
(0.784-1.592)\end{array}$ & $\begin{array}{l}1.063 \\
(0.773-1.463)\end{array}$ & & & \\
\hline Higher & $\begin{array}{l}1.421 \\
(0.722-2.796)\end{array}$ & $\begin{array}{l}1.266 \\
(0.702-2.283)\end{array}$ & $\begin{array}{l}1.109 \\
(0.634-1.939)\end{array}$ & & & \\
\hline \multicolumn{7}{|l|}{ Mother's working status } \\
\hline No & Ref & Ref & Ref & & & \\
\hline Yes & $\begin{array}{l}1.006 \\
(0.625-1.618)\end{array}$ & $\begin{array}{l}1.022 \\
(0.687-1.519)\end{array}$ & $\begin{array}{l}1.051 \\
(0.737-1.498)\end{array}$ & & & \\
\hline
\end{tabular}


Table 5 Unadjusted and adjusted regression analysis (Continued)

\begin{tabular}{|c|c|c|c|c|c|c|}
\hline \multirow{3}{*}{ Variable } & \multicolumn{6}{|c|}{ Unadjusted and Adjusted Regression Analysis } \\
\hline & \multicolumn{3}{|c|}{ Unadjusted Analysis } & \multicolumn{3}{|c|}{ Adjusted Analysis } \\
\hline & $\begin{array}{l}\text { Neonatal } \\
\text { Mortality }\end{array}$ & $\begin{array}{l}\text { Infant } \\
\text { Mortality }\end{array}$ & Under-five mortality & $\begin{array}{l}\text { Neonatal } \\
\text { Mortality }\end{array}$ & $\begin{array}{l}\text { Infant } \\
\text { Mortality }\end{array}$ & Under-five mortality \\
\hline \multicolumn{7}{|l|}{ Mother's mass media usage } \\
\hline Yes & Ref & Ref & Ref & Ref & Ref & Ref \\
\hline Not at All & $\begin{array}{l}1.312 \\
(0.970-1.775)\end{array}$ & $\begin{array}{l}1.405 \\
(1.096-1.803)^{*}\end{array}$ & $\begin{array}{l}1.186 \\
(0.936-1.502)\end{array}$ & $\begin{array}{l}2.715 \\
(1.392-5.292)^{*}\end{array}$ & $\begin{array}{l}1.697 \\
(1.001-2.877)^{*}\end{array}$ & $\begin{array}{l}1.599 \\
(0.942-2.715)\end{array}$ \\
\hline \multicolumn{7}{|l|}{ Maternal Factors } \\
\hline \multicolumn{7}{|l|}{ Desire for pregnancy } \\
\hline Then & Ref & Ref & Ref & & & \\
\hline Later & $\begin{array}{l}0.558 \\
(0.339-0.921)^{*}\end{array}$ & $\begin{array}{l}0.682 \\
(0.443-1.050)\end{array}$ & $\begin{array}{l}0.681 \\
(0.465-0.999)^{*}\end{array}$ & & & \\
\hline No more & $\begin{array}{l}1.124 \\
(0.656-1.927)\end{array}$ & $\begin{array}{l}1.012 \\
(0.632-1.621)\end{array}$ & $\begin{array}{l}0.954 \\
(0.618-1.473)\end{array}$ & & & \\
\hline \multicolumn{7}{|l|}{ Mother's BMI } \\
\hline$<18.5$ & Ref & Ref & Ref & Ref & Ref & Ref \\
\hline$>=18.5$ & $\begin{array}{l}1.237 \\
(0.734-2.086)\end{array}$ & $\begin{array}{l}1.607 \\
(1.015-2.545)^{*}\end{array}$ & $\begin{array}{l}1.572 \\
(1.036-2.386)^{*}\end{array}$ & $\begin{array}{l}2.445 \\
(1.071-5.583)^{*}\end{array}$ & $\begin{array}{l}2.668 \\
(1.304-5.457)^{*}\end{array}$ & $\begin{array}{l}2.383 \\
(1.206-4.710)^{*}\end{array}$ \\
\hline \multicolumn{7}{|l|}{ Mother giving sexual favors } \\
\hline No & Ref & Ref & Ref & & & \\
\hline Yes & $\begin{array}{l}1.245 \\
(0.496-3.126)\end{array}$ & $\begin{array}{l}1.255 \\
(0.429-3.669)\end{array}$ & $\begin{array}{l}1.147 \\
(0.417-3.156)\end{array}$ & & & \\
\hline \multicolumn{7}{|l|}{ Health System Factors } \\
\hline \multicolumn{7}{|l|}{ Delivery by Caesarean section } \\
\hline No & Ref & Ref & Ref & Ref & & \\
\hline Yes & $\begin{array}{l}1.551 \\
(0.821-2.929)\end{array}$ & $\begin{array}{l}1.351 \\
(0.819-2.28)\end{array}$ & $\begin{array}{l}1.332 \\
(0.858-2.069)\end{array}$ & $\begin{array}{l}2.108 \\
(0.894-4.971)\end{array}$ & & \\
\hline \multicolumn{7}{|l|}{ Delivery assistance } \\
\hline Non-health professional & Ref & Ref & Ref & & & \\
\hline Health professional & $\begin{array}{l}1.002 \\
(0.740-1.357)\end{array}$ & $\begin{array}{l}1.049 \\
(0.823-1.337)\end{array}$ & $\begin{array}{l}0.999 \\
(0.805-1.240)\end{array}$ & & & \\
\hline \multicolumn{7}{|l|}{ Place of delivery } \\
\hline Home delivery & Ref & Ref & Ref & & & \\
\hline Hospital/other & $\begin{array}{l}0.996 \\
(0.748-1.326)\end{array}$ & $\begin{array}{l}1.030 \\
(0.818-1.296)\end{array}$ & $\begin{array}{l}0.967 \\
(0.787-1.189)\end{array}$ & & & \\
\hline \multicolumn{7}{|l|}{ Antenatal care } \\
\hline No & Ref & Ref & Ref & Ref & Ref & Ref \\
\hline Yes & $\begin{array}{l}0.258 \\
(0.157-0.425)^{*}\end{array}$ & $\begin{array}{l}0.347 \\
(0.229-0.525)^{*}\end{array}$ & $\begin{array}{l}0.368 \\
(0.246-0.549)^{*}\end{array}$ & $\begin{array}{l}0.418 \\
(0.200-0.875)^{*}\end{array}$ & $\begin{array}{l}0.528 \\
(0.269-1.035)\end{array}$ & $\begin{array}{l}0.614 \\
(0.315-1.196)\end{array}$ \\
\hline \multicolumn{7}{|l|}{ Contraceptive use } \\
\hline Not using & Ref & Ref & Ref & Ref & Ref & Ref \\
\hline Using & $\begin{array}{l}0.683 \\
(0.513-0.910)^{*}\end{array}$ & $\begin{array}{l}0.671 \\
(0.534-0.841)^{*}\end{array}$ & $\begin{array}{l}0.622 \\
(0.507-0.763)^{*}\end{array}$ & $\begin{array}{l}0.409 \\
(0.248-0.673)^{*}\end{array}$ & $\begin{array}{l}0.404 \\
(0.254-0.644)^{*}\end{array}$ & $\begin{array}{l}0.370 \\
(0.233-0.589)^{*}\end{array}$ \\
\hline \multicolumn{7}{|l|}{ Paternal Factors } \\
\hline \multicolumn{7}{|l|}{ Husband/partner's age } \\
\hline$<29$ years & Ref & Ref & Ref & & & \\
\hline 30-39 years & $\begin{array}{l}0.626 \\
(0.342-1.146)\end{array}$ & $\begin{array}{l}0.716 \\
(0.438-1.170)\end{array}$ & $\begin{array}{l}0.726 \\
(0.467-1.127)\end{array}$ & & & \\
\hline
\end{tabular}


Table 5 Unadjusted and adjusted regression analysis (Continued)

\begin{tabular}{|c|c|c|c|c|c|c|}
\hline \multirow{3}{*}{ Variable } & \multicolumn{6}{|c|}{ Unadjusted and Adjusted Regression Analysis } \\
\hline & \multicolumn{3}{|c|}{ Unadjusted Analysis } & \multicolumn{3}{|c|}{ Adjusted Analysis } \\
\hline & $\begin{array}{l}\text { Neonatal } \\
\text { Mortality }\end{array}$ & $\begin{array}{l}\text { Infant } \\
\text { Mortality }\end{array}$ & Under-five mortality & $\begin{array}{l}\text { Neonatal } \\
\text { Mortality }\end{array}$ & $\begin{array}{l}\text { Infant } \\
\text { Mortality }\end{array}$ & Under-five mortality \\
\hline 40-49 years & $\begin{array}{l}0.758 \\
(0.406-1.413)\end{array}$ & $\begin{array}{l}0.761 \\
(0.459-1.259)\end{array}$ & $\begin{array}{l}0.734 \\
(0.461-1.166)\end{array}$ & & & \\
\hline 50 plus years & $\begin{array}{l}0.950 \\
(0.449-2.007)\end{array}$ & $\begin{array}{l}0.743 \\
(0.387-1.427)\end{array}$ & $\begin{array}{l}0.829 \\
(0.469-1.464)\end{array}$ & & & \\
\hline \multicolumn{7}{|l|}{ Father's working status } \\
\hline No & Ref & Ref & Ref & & & \\
\hline Yes & $\begin{array}{l}1.248 \\
(0.402-3.874)\end{array}$ & $\begin{array}{l}1.645 \\
(0.604-4.484)\end{array}$ & $\begin{array}{l}1.486 \\
(0.596-3.700)\end{array}$ & & & \\
\hline \multicolumn{7}{|l|}{ Sex of child } \\
\hline Male & Ref & Ref & Ref & & & \\
\hline Female & $\begin{array}{l}0.837 \\
(0.647-1.084)\end{array}$ & $\begin{array}{l}0.852 \\
(0.689-1.052)\end{array}$ & $\begin{array}{l}0.897 \\
(0.741-1.086)\end{array}$ & & & \\
\hline \multicolumn{7}{|l|}{ Size of child at birth } \\
\hline Average or larger & Ref & Ref & Ref & Ref & Ref & Ref \\
\hline Small or very small & $\begin{array}{l}2.328 \\
(1.555-3.487)^{*}\end{array}$ & $\begin{array}{l}1.703 \\
(1.209-2.399)^{*}\end{array}$ & $\begin{array}{l}1.739 \\
(1.263-2.394)^{*}\end{array}$ & $\begin{array}{l}2.202 \\
(1.350-3.592)^{*}\end{array}$ & $\begin{array}{l}1.659 \\
(1.047-2.630)^{*}\end{array}$ & $\begin{array}{l}1.564 \\
(1.003-2.438)^{*}\end{array}$ \\
\hline Don't know & $\begin{array}{l}4.925 \\
(1.852-13.09)^{*}\end{array}$ & $\begin{array}{l}2.897 \\
(1.110-7.560)^{*}\end{array}$ & $\begin{array}{l}2.610 \\
(1.044-6.526)^{*}\end{array}$ & $\begin{array}{l}5.792 \\
(1.730-19.39)^{*}\end{array}$ & $\begin{array}{l}4.288 \\
(1.108-16.60)^{*}\end{array}$ & $\begin{array}{l}3.440 \\
(0.883-13.39)\end{array}$ \\
\hline \multicolumn{7}{|l|}{ Birth weight (Kg) } \\
\hline$<2500$ & Ref & Ref & Ref & & & \\
\hline $2500-3500$ & $\begin{array}{l}0.226 \\
(0.126-0.408)^{*}\end{array}$ & $\begin{array}{l}0.276 \\
(0.145-0.526)^{*}\end{array}$ & $\begin{array}{l}0.273 \\
(0.151-0.494)^{*}\end{array}$ & & & \\
\hline$>3500$ & $\begin{array}{l}0.382 \\
(0.147-0.994)^{*}\end{array}$ & $\begin{array}{l}0.556 \\
(0.254-1.218)\end{array}$ & $\begin{array}{l}0.530 \\
(0.259-1.087)\end{array}$ & & & \\
\hline Not weighed & $\begin{array}{l}0.755 \\
(0.402-1.417)\end{array}$ & $\begin{array}{l}0.657 \\
(0.343-1.259)\end{array}$ & $\begin{array}{l}0.648 \\
(0.360-1.167)\end{array}$ & & & \\
\hline Don't know & $\begin{array}{l}3.781 \\
(1.219-11.73)^{*}\end{array}$ & $\begin{array}{l}2.846 \\
(0.954-8.492)\end{array}$ & $\begin{array}{l}2.363 \\
(0.816-6.841)\end{array}$ & & & \\
\hline \multicolumn{7}{|l|}{ Birth order and interval } \\
\hline 2nd/3rd child, $>2$ years & Ref & Ref & Ref & & & Ref \\
\hline 1st child & $\begin{array}{l}1.285 \\
(0.937-1.761)\end{array}$ & $\begin{array}{l}1.128 \\
(0.842-1.513)\end{array}$ & $\begin{array}{l}1.112 \\
(0.848-1.459)\end{array}$ & & & $\begin{array}{l}0.608 \\
(0.309-1.195)\end{array}$ \\
\hline 2nd/3rd child, $\leq 2$ years & $\begin{array}{l}0.990 \\
(0.641-1.529)\end{array}$ & $\begin{array}{l}0.966 \\
(0.675-1.383)\end{array}$ & $\begin{array}{l}0.932 \\
(0.666-1.305)\end{array}$ & & & $\begin{array}{l}0.615 \\
(0.250-1.513)\end{array}$ \\
\hline 4th/higher child, $>2$ years & $\begin{array}{l}1.028 \\
(0.749-1.411)\end{array}$ & $\begin{array}{l}0.941 \\
(0.723-1.225)\end{array}$ & $\begin{array}{l}0.978 \\
(0.768-1.245)\end{array}$ & & & $\begin{array}{l}1.075 \\
(0.675-1.713)\end{array}$ \\
\hline 4th/higher child, $\leq 2$ years & $\begin{array}{l}1.713 \\
(1.203-2.439)^{*}\end{array}$ & $\begin{array}{l}1.824 \\
(1.313-2.533)^{*}\end{array}$ & $\begin{array}{l}1.869 \\
(1.377-2.537)^{*}\end{array}$ & & & $\begin{array}{l}1.945 \\
(0.874-4.330)\end{array}$ \\
\hline
\end{tabular}

Two asterisks $\left(^{* *}\right)$ denotes the $p$-value is $<0.001$, and one asterisk $\left(^{*}\right)$ denotes the $p$-value is $<0.05$

occurred in the past. Given the stigma surrounding IPV in sub-Saharan Africa, IPV exposure is underreported, which limits the generalizability of these findings across the countries analyzed. In addition, the cross-sectional nature of DHS data limits the likelihood of showing causal relations between IPV against women and neonatal, infant, and children under-five mortality rates. Also, it is challenging to determine whether the mortality rates preceded IPV or vice versa. Despite the limitations, this study examines different multi-level variables in relation to IPV. These findings provide a snapshot of the current association between IPV and infant and child mortality rates and can be used to facilitate contextualized interventions and strategies across East African countries. 


\section{Conclusion}

Our study findings revealed that women exposed to IPV were more likely to experience the death of a child. Antenatal care, sexual autonomy, perceived and actual birth weight, child birth order/interval, and socioeconomic indicators were significantly associated with IPV. This study revealed that IPV plays a negative role in neonatal, infant, and child mortality in East Africa and other resourcelimited countries. To that end, IPV against women is a public health issue that not only negatively affects mothers but their children as well. Current and future interventions can only be sustained by adequate funding and policies that support women's and children's rights.

\section{Abbreviations}

AIDS: Acquired immune deficiency syndrome; BMI: Body mass index; Cl: Confidence interval; DHS: Demographic Health Survey; HIV: Human immunodeficiency virus; IM: Infant mortality; IMR: Infant mortality rate; IPV: Intimate partner violence; LMIC: Low- and middle-income country; NM: Neonatal mortality; NMR: Neonatal mortality rate; OR (aOR): (Adjusted) odds ratio; UM: Under-five mortality; UMR: Under-five mortality rate; WHO: World Health Organization

\section{Acknowledgements}

We acknowledge the Askew Institute for Multidisciplinary Studies (AIMS) for providing the author with time to conduct this research. We thank MEASURE DHS for providing the full data set to conduct this important study.

\section{Authors' contributions}

PM conceived and designed the study. PM and $Y O$ assisted the study design. $\mathrm{KO}$ and PM analyzed the data. PM, TB, YO assisted the analysis, interpreted the data, and wrote the manuscript. TB, CC, NGK, MM, CK, DM conducted a detailed literature review, analysis, and synthesis of the manuscript. All authors critically reviewed and approved the manuscript and meet ICMJE criteria for authorship.

\section{Funding}

This research received no specific grant from any funding agency in the public, commercial, or not-for-profit sectors.

\section{Availability of data and materials}

Data was requested from the DHS program via email (https://dhsprogram. com/what-we-do/survey-Types/dHs.cfm). The data used for this study can be obtained through DHS (http://dhsprogram.com/) and are available upon request from the corresponding author.

\section{Ethics approval and consent to participate}

The study used secondary data from Measure DHS and does not require ethical approval.

\section{Consent for publication}

Not applicable

\section{Competing interests}

The authors declare that they have no competing interests.

\section{Author details}

${ }^{1}$ Division of Epidemiology and Prevention, Institute of Human Virology (IHV): University of Maryland School of Medicine, 725 W. Lombard Street, Baltimore, MD 21201, USA. ${ }^{2}$ Amref Health Africa: Lang'ata Road, Amref Health Africa Headquarters, Nairobi, Kenya. ${ }^{3}$ College of Health Sciences and Professions; Department of Social and Public Health, Ohio University Grover Center W347, 45701 Athens, OH, USA. ${ }^{4}$ BiologyDepartment, University of West Florida, Building 58, Room 79, 11000 University Parkway Pensacola, Pensacola, FL 32514, USA. ${ }^{5}$ Department of Economics, University of Nairobi, P.O Box 30197-00100, GPO, Nairobi, Kenya. ${ }^{6}$ Institute of Tropical Medicine and Infectious Disease, KEMRI, Kenya. 'University of Maryland; School of Medicine, Baltimore, USA. ${ }^{8}$ Centre for Health Solutions, Nairobi, Kenya.

Received: 4 December 2018 Accepted: 12 December 2019

Published online: 23 January 2020

\section{References}

1. WHO. Violence against Women [Internet]. 2017. Available from: https:// www.who.int/news-room/fact-sheets/detail/violence-against-women

2. Garcia-Moreno C, Guedes A. Knerr W. Geneva: Understanding and addressing violence against women; 2012.

3. WHO. Violence By Intimate Partners. World Report on Violence and Health. 2012.

4. Kelly JT, Betancourt TS, Mukwege D, Lipton R, Vanrooyen MJ. Experiences of female survivors of sexual violence in eastern Democratic Republic of the Congo: a mixed-methods study. Confl Health. 2011.

5. Campbell JC, Soeken KL. Forced sex and intimate partner Violence. Violence Against Women. 1999 Sep;5(9):1017-35.

6. Campbell JC, Baty ML, Ghandour RM, Stockman JK, Francisco L, Wagman J. The intersection of intimate partner violence against women and HIV/AIDS: a review. Int J Inj Control Saf Promot. 2008 Dec;15(4):221-31.

7. Ahmed S, Koenig MA, Stephenson R. Effects of Domestic Violence on Perinatal and Early-Childhood Mortality: Evidence from North India. Am J Public Health. 2006;96(8):1423-8 Available from: http://www.ncbi.nlm.nih. gov/pubmed/16809594.

8. WHO. Infant Mortality: Situation and Trends [Internet]. Global Health Observatory (GHO) data. World Health Organization; 2015 2017. Available from: http://www.who.int/gho/child_health/mortality/neonatal_infant_text/en/

9. The United Nations. Sustainable Development Goals. 2015.

10. The United Nations. Sustainable Development Goal 5. 2015.

11. Rau A. Causes of child mortality in developing countries. The Borgen Project. 2015.

12. UNICEF. UNICEF Tanzania - Maternal \& Child Health - The Situation. UNICEF. 2010 2017. Available from: https://www.unicef.org/tanzania/maternal_child_ health.html

13. Bin NY, Dibley MJ. Determinants of neonatal mortality in Pakistan: Secondary analysis of Pakistan Demographic and Health Survey 2006-07. BMC Public Health. 2014;14, 663. https://doi.org/10.1186/1471-2458-14-663

14. USAID. Standard Recode Manual for Dhs 6. DHS Publ. 2013;1-7.

15. Mosley WH. Biological and socioeconomic determinants of child survival | Determinantes biológicos y socioeconómicos de la sobrevivencia en la infancia. Salud Publica Mex. 1988;30(3):312-28.

16. Hossain MA, Sumi NS, Haque ME, Bari W. Consequences of intimate partner Violence Against Women on under-five child mortality in Bangladesh. J Interpers Violence. 2014;29(8):1402-17 Available from: http://journals. sagepub.com/doi/10.1177/0886260513507140.

17. Silverman JG, Decker MR, Cheng DM, Wirth K, Saggurti N, McCauley HL, et al. Gender-based disparities in infant and child mortality based on maternal exposure to spousal Violence: the heavy burden borne by Indian girls. Arch Pediatr Adolesc Med. 2011;165(1):22-7 Available from: http:// archpedi.jamanetwork.com/article.aspx?doi=10.1001/archpediatrics.2010.261.

18. Rico E, Fenn B, Abramsky T, Watts C. Associations Between Maternal Experiences of Intimate Partner Violence and Child Nutrition and Mortality: Findings from Demographic and Health Surveys in Egypt, Honduras, Kenya, Malawi and Rwanda. J Epidemiol Community Heal. 2011;65(4):360-7 Available from: http://www.ncbi.nlm.nih.gov/pubmed/20841374.

19. Devries K, Watts C, Yoshihama M, Kiss L, Schraiber LB, Deyessa N, et al. Violence Against Women is Strongly Associated with Suicide Attempts: Evidence from the WHO Multi-Country Study on Women's Health and Domestic Violence Against Women. Soc Sci Med. 2011;73(1):79-86 Available from: http://www.ncbi.nlm.nih.gov/pubmed/21676510.

20. Al-Adawi S, Al-Bahlani S. Domestic Violence: "What's Love Got To Do With It?". Sultan Qaboos Univ Med J. 2007;7(1):5-14 Available from: http://www. ncbi.nlm.nih.gov/pubmed/21654939.

21. Rahman M, Poudel KC, Yasuoka J, Otsuka K, Yoshikawa K, Jimba M. Maternal Exposure to Intimate Partner Violence and the Risk of Undernutrition Among Children Younger Than 5 Years in Bangladesh. Am J Public Health. 2012;102(7): 1336-45 Available from: http://www.ncbi.nlm.nih.gov/pubmed/22676499.

22. Mason SM, Ayour N, Canney S, Eisenberg ME, Neumark-Sztainer D. Intimate partner Violence and 5-year weight change in young Women: a 
longitudinal Study. J Women's heal. 2017;26(6):677-82 Available from: http://www.ncbi.nlm.nih.gov/pubmed/28075656.

23. Alio AP, Daley EM, Nana PN, Duan J, Salihu HM. Intimate Partner Violence and Contraception Use Among Women in Sub-Saharan Africa. Int J Gynecol Obstet. 2009;107(1):35-8 Available from: http://www.ncbi.nlm.nih.gov/ pubmed/19481751.

24. Maxwell L, Devries K, Zionts D, Alhusen JL, Campbell J. Estimating the Effect of Intimate Partner Violence on Women's Use of Contraception: A Systematic Review and Meta-Analysis. PLoS One. 2015;10(2):e0118234 Available from: http://www.ncbi.nlm.nih.gov/pubmed/25693056.

25. Mohammed BH, Johnston JM, Harwell JI, Yi H, Tsang KW, Haidar JA. Intimate Partner Violence and Utilization of Maternal Health Care Services in Addis Ababa, Ethiopia. BMC Health Serv Res. 2017;17(1):178 Available from: http:// www.ncbi.nlm.nih.gov/pubmed/28270137.

26. Wandera SO, Kwagala B, Odimegwu C. Intimate Partner Violence and Current Modern Contraceptive Use Among Married Women in Uganda: A Cross-Sectional Study. Pan Afr Med J. 2018;30:85 Available from: http://www. panafrican-med-journal.com/content/article/30/85/full/.

27. Dutton MA, James L, Langhorne A, Kelley M. Coordinated public Health initiatives to address Violence Against Women and adolescents. J Women's Heal. 2015;24(1):80-5.

\section{Publisher's Note}

Springer Nature remains neutral with regard to jurisdictional claims in published maps and institutional affiliations.

Ready to submit your research? Choose BMC and benefit from:

- fast, convenient online submission

- thorough peer review by experienced researchers in your field

- rapid publication on acceptance

- support for research data, including large and complex data types

- gold Open Access which fosters wider collaboration and increased citations

- maximum visibility for your research: over $100 \mathrm{M}$ website views per year

At BMC, research is always in progress.

Learn more biomedcentral.com/submissions 